\title{
International(ization of) Higher Education at the Crossroads
}

\section{Hans De Wit and Fiona Hunter}

Hans de Wit is Director of the Centre for Higher Education Internationalisation (CHEI) at the Università Cattolica del Sacro Cuore in Milan, Italy, and Professor of Internationalization of higher Education at the Amsterdam University of Applied Sciences. E-mail: j.w.m.de.wit@hva. nl. Fiona Hunter is Research Associate at the Center in Milan, coeditor of the Journal of Studies in International Education and consultant, trainer, and researcher in higher education. E-mail: fionajanehunter@ gmail.com. They are the editors of this annual special issue on internationalization of higher education for International Higher Education, a collaboration between $\mathrm{CHEI}$ and the Boston College Center for International Higher Education. .

I nternational higher education is best described as the study of higher education in its international and global context. Globalization, the increasing importance of knowledge in economy and society, massification and internationalization have moved higher education from being primarily national in orientation to the international forefront. International Higher Education, the Center at Boston College that publishes this newsletter and in particular its director, Philip G. Altbach, is closely associated with this field, if not the founder of it. It is a topic of wide interest and growing policy relevance. As Altbach has described it in 20I3: "Globalization has brought the international role of universities to prominence and has greatly expanded the scope of campus internationalization." With this statement, he brings the two fields, international higher education and internationalization of higher education, together. Where international higher education broadly analyzes international developments in higher education at the system level, internationalization can be seen as a subcategory of this work-focusing more specifically on the international rationales, approaches, strategies, activities; outcomes of higher education at the regional, national; and institutional level, and (where possible) in a comparative perspective.

It would take too much space and debate to set clear demarcating lines between the two fields, given that the two are more than ever now intertwined. International Higher Education, as well as other higher education journals and books, increasingly include contributions on internationalization of higher education, while those which focus more specifically on the latter, such as the Journal of Studies in International Education, address internationalization more broadly in a systematic, international, and global context. Why, then, a special issue of International Higher Educa- tion dedicated specifically to internationalization, instead of continuing to include contributions on this topic in the regular issues-something that will also happen in the future in any case?

While it is indeed a fact that internationalization has become a key pillar both in higher education in practice and in scholarship in the field, the focus is still predominantly on some of its components and aspects, in particular the mobility of students and scholars as well as, more recently, programs and projects, also described as transnational education or cross-border delivery of education. There is another dimension to internationalization: the curriculum, teaching and learning and learning outcomes, sometimes also described as internationalization at home, which is receiving less attention, along with the relation between mobility and the "at home" aspects. This special issue seeks to

\section{This Special Issue seeks to highlight new and innovative dimensions in in- ternationalization.}

highlight new and innovative dimensions in internationalization. It also gives space to developments in internationalization of higher education in regions and countries that are less known than English-speaking countries and western Europe. And it illustrates the increasing importance and diversity of internationalization (in terms of concepts and "lived realities") in modern international higher education. The contributions to this first special issue are a manifestation of these rationales.

As editors of the special issue and as director and research associate of the Centre for Higher Education Internationalization at the Università Cattolica del Sacro Cuore in Milan, Italy, we are looking forward to this collaboration between our two Centers in this publication and invite you to propose contributions for its next annual issue. 